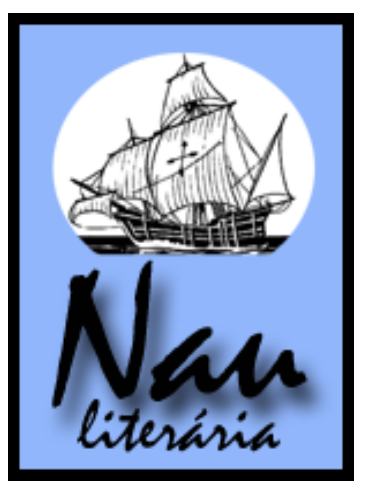

\title{
Adeus Luanda Um breve olhar sobre $O$ retorno, de Dulce Maria Cardoso
}

\section{Alleid Ribeiro Machado*}

\begin{abstract}
Resumo: Em O retorno (2012), Dulce Maria Cardoso convida-nos a conhecer a história de Rui, um adolescente "retornado" de Angola que, junto a sua família, é obrigado a recomeçar a vida em Portugal Continental, a partir de uma situação financeira precária e limitada. O cenário é a década de 70 e o conturbado período de retorno de mais de meio milhão de cidadãos portugueses, durante a descolonização dos antigos territórios ultramarinos em África. Este artigo buscou compreender as reflexões levadas a efeito pelo adolescente protagonista d'O retorno, em meio a uma narrativa que discursivamente realiza-se face ao sentimento de não-pertencimento. Para tanto, fizemos um breve apanhado histórico do período que se iniciou no final dos anos 50 e que se seguiu após 1974, trazendo para primeiro plano a questão da migração portuguesa, além de considerar o contexto literário em que o livro em pauta foi produzido.
\end{abstract}

Palavras-chave: mal-estar; exílio; não-pertencimento; literatura portuguesa contemporânea

\begin{abstract}
In $O$ retorno (2012), Dulce Maria Cardoso invites us to know the Rui's history, a "returnee" teenager that was born in Angola who, along his family, is compelled to restart his life in Continental Portugal, from a limited and precarious financial situation. The context is the 70's and the disturbed period of return of more than a half of a million Portuguese citizens to the Continent, during the decolonization of its overseas territories in Africa. This article pursued to comprehend the reflections of the young protagonist of $O$ retorno, in middle of a narrative which is discussed by the feeling of not belonging. Thus, we did a brief historical resume of the period, from the end of 50's to nowadays, bringing to the first plan the Portuguese migration issue, besides considering the literary context in which the book was yield.
\end{abstract}

Keywords: discomfort; exile; not belonging; contemporary Portuguese literature

contemporary Portuguese literature

\begin{abstract}
A verdade deve estar unida e ser infragmentada, enquanto o real pode ser - tem de ser porque senão explodiria - disperso e irrelevante, escorregando, como sabe, literalmente, para local nenhum. (Lídia Jorge, A costa dos murmúrios).
\end{abstract}


Ainda sob o influxo do salazarismo e vivendo sob a égide de um país economicamente antiquado em relação ao resto da Europa, Portugal será marcado por dois grandes processos imperativos para sua história contemporânea. Em um plano, a intensa emigração portuguesa para França, que se tratava de um deslocamento, sobretudo, marcado por uma profunda descrença nas capacidades de desenvolvimento de Portugal. Joel Serrão é taxativo em advertir que, entre 1958 e 1974, cerca de um milhão de portugueses instalaram-se em França, à procura de oportunidades de trabalho (cf. SERRÃO, 1982, p. 15-30). Em outro plano, em 1961, revive-se o processo de perda territorial que seria absolutamente dispendioso a uma nação colonialista por excelência: a perda das colônias portugueses em África (nomeadamente Angola e Moçambique) e, para além, as possessões em Guiné (atual Guiné-Bissau), Cabo Verde e São Tomé e Príncipe, que se manteve até 1974-75. Portugal, sustentando a presença militar e civil em todos esses territórios por ele colonizados, em meio à conjuntura de guerras e revoltas, gradativamente, vai deixando de garantir os dividendos econômicos que lhe eram suficientes para prosseguir em seu projeto imperialista. Desencadeia-se, assim, a Guerra Colonial, que só o 25 de abril de 1974 deverá pôr termo, ao reconhecer a independência de todos os seus territórios em África.

Do lado africano, por seu turno, mais precisamente em Angola, nos anos 60, a história de um novo destino também começava a configurar-se, pois era iniciada a sua luta independentista sob o pretexto de colocar ponto final na presença portuguesa em África.

Em 1961, iniciou-se a revolução na "África Portuguesa." Ela também encontraria seus limites em problemas herdados e de longa duração. A África Negra, cercada por dois mares e dois desertos (o Atlântico e o Índico; o Saara e o Kalahari), exibia recursos naturais, exibia suas rotas ancestrais, cedo desabadas. Faltavam forças produtivas para lograr a realização do ideário socialista que foi adotado por muitos de seus líderes. Por direta responsabilidade dos colonizadores europeus, esta África teve que mergulhar na revolução, na guerra de libertação nacional e na guerra civil (SECCO, 2005, p. 11).

Há tempos que os povos africanos desejavam construir uma identidade que refletisse a cultura e as raízes suprimidas pela colonização. No caso português, suas colônias já eram uma amostra de um "império periférico" (cf. SANTOS, 2002, p. 84) ultrapassado pelo próprio alargamento do capitalismo e das forças produtivas, que cedia cada vez mais a exploração delas ao capital estrangeiro (cf. AUGUSTO, 2011, p. 22-29).

No que se refere à ficção, a literatura contemporânea, nomeadamente aquela produzida após a década de 70, ou, mais precisamente, após a Revolução dos Cravos, motivada por todo esse cenário político-histórico transformador, principalmente no domínio da recente democracia em curso, e pelo desejo de transformação da literatura, conceberá novas formas de representação literária nos âmbitos da prosa e da poesia. Trata-se de um período que se inicia 
fecundo para a renovação estética da escrita, seja pela introdução de temáticas ligadas aos aspectos e nuances de uma cultura a rever a sua própria identidade de país-colonizador, mas periférico em relação ao resto da Europa, seja na exploração de conteúdos relativamente próprios ao contexto de uma modernidade cujos ecos se faziam sentir Portugal adentro.

O 25 de abril transformou a vida de todos os portugueses, modificando as instituições sociais e, sobretudo, influenciando o âmbito artístico lusitano. Esse acontecimento histórico influenciou a atividade escritural dos autores, demonstrando uma estreita vinculação das alterações sociais com a renovação do próprio percurso artístico dos escritores portugueses anteriores e subsequentes a 1974 (ROANI, 2006, p. 23-24).

O terreno para frutificação de uma literatura de ruptura com os veios da literatura tradicional e colonialista havia sido preparado, principalmente no âmbito da poesia, pelas fases de experimentação poética oriundas, por sua vez, do influxo das vanguardas europeias. Nesse sentido, o engajamento proposto pelo neorrealismo e a proposta transgressora levada a efeito pelos poetas da Poesia 61, apenas para citar os casos mais importantes, foram adjuvantes para o fortalecimento das potencialidades discursivas no campo ficcional, agora passível de revisitar o passado ou imaginar o futuro "sob as lentes críticas da ironia, da intertextualidade, da paródia, de modo a rever os mitos e as mentalidades da história portuguesa, ou o reflexo deles no próprio tempo de produção" (MACHADO, 2012, p. 184). Dessa forma, toda a produção literária pós-Revolução dos Cravos deverá ser marcada pela heterogeneidade dos autores e de seus ideais estéticos. Assim,

no que diz respeito às opções formais, o que sobressai é a multiplicidade e a diferenciação a nível dos modos narrativos e discursivos. A par de uma representação mais tradicional, presente em alguns livros [...], os restantes são testemunho de uma manifesta postura experimentalista, os traços mais pertinentes desta aventura relacionam-se com técnicas mais ousadas, como é o caso do recurso à ironia, à paródia e ao pastiche, que conseguem carnavalizar estruturas e estilos (PETROV, 2005, p. 9-10).

No entanto, um pouco anterior à revolução, ainda sob o influxo da repressão salazarista, algumas obras literárias já dariam mostras das características que viriam a consolidar a literatura contemporânea, como as citadas por Petrov, justamente por apresentarem mecanismos que incomodavam as instâncias de censura da liberdade de expressão. O objetivo comum, em todo caso, era o de romper igualmente com a ordem e o poder dominantes. Não podemos afirmar que essa literatura houvesse sido escrita, exclusivamente, para refletir o sentimento de insatisfação com o contexto histórico e cultural lusitano, todavia não é demasiado admitir que, não obstante, uma grande gama de autores se envolveu no projeto de alçar voz contra esse delicado momento histórico, assumindo, de tal modo, quer na esfera da prosa e da poesia, ou quer da dramaturgia, uma postura de 
enfrentamento que deixava clara a intenção revolucionária, como vai ocorrer, por exemplo, com a publicação d'As novas cartas portuguesas (1974), das autoras Maria Isabel Barreno, Maria Teresa Hora e Maria Velho da Costa, apenas para citar um caso.

De qualquer forma, se a literatura portuguesa produzida a partir da década de 70 , principalmente no âmbito da prosa, procurou dialogar com as questões pertinentes ao cenário histórico-político, como as que se referiam em larga escala à revolução e à Guerra Colonial, a literatura produzida após a década de 80 , em face ao novo cenário de influências pósmodernistas, procurará refletir diversas e amplas temáticas, desde as relacionadas às mulheres e à agenda feminista (cf. MACHADO, 2012, p. 165-172), até às questões atinentes à sondagem dos sentimentos e das angústias dos que estiveram direta ou indiretamente envolvidos na moderna diáspora portuguesa. Igualmente, revelar-se-á como tendência do novo romance português, especialmente a partir dos anos 90, “a revisitação africana que, deste modo, propõe-se examinar a identidade do Portugal colonial e pós-imperial" (GOULD, 2007, p. 65). Tal revisitação terá como mola propulsora principal o discurso perturbador da memória, resgatando para o presente pós-colonial as mazelas com que foram construídas e, depois, destruídas, as bases coloniais nos territórios portugueses em África.

Numa espécie de contra-discurso, não orquestrado como tal, mas que hoje pode ser lido como tal, a ficção portuguesa do pós-25 de abril ia mostrando a importância da memória, não só como essencial à construção da democracia, mas como seu elemento fundamental. De José Cardoso Pires, António Lobo Antunes, Mário de Carvalho, José Saramago, Maria Velho da Costa aos mais jovens Valter Hugo Mãe ou Dulce Maria Cardoso, as dores e as heranças da ditadura são temas; noutra dimensão, o império e sua herança povoam a literatura portuguesa contemporânea, tanto com memórias douradas desse tempo, como com memórias cinzentas da brutalidade do colonialismo e da Guerra Colonial que pôs fim ao império. (RIBEIRO, 2012, p. 90).

Implicado ao resgate do passado recente português, virá a lume a necessidade de pôr em causa as experiências dos colonos, dos que perderam com o fim do império. Dos retornados e sua permanente tensão de pertencimento e não-pertencimento, da conflitante identidade de ser colono e português de segunda classe. Portanto, essa breve contextualização histórico-política e literária abrangendo um período que se inicia no final dos anos 50 e que se segue após 1974, serve-nos como ponto de apoio para entendermos como os fatos históricos serão refratados em relação a tais acontecimentos e, consequentemente, transformados em matéria ficcional, principalmente, ao levarmos em consideração as reflexões engendradas pelo adolescente Rui em $O$ retorno, romance de autoria feminina, a retratar a experiência diaspórica moderna de um povo obrigado a deitar raiz num lar ancestral, mas que lhe era, ao mesmo tempo, peculiar e suspeito. 


\section{Luanda para sempre na memória}

Como observamos, quarenta anos depois do fim da Guerra Colonial (1961-1975), o interesse da literatura portuguesa contemporânea por esse período da história recente continua em pauta. As causas e as consequências e, para além, as vivências do império colonial e de seu fim, tem se frutificado na rememoração desse período. E isso tem ocorrido também nas vozes dos "retornados" - termo pelo qual foram designados os portugueses que, em 1975, com a independência das províncias ultramarinas, foram obrigados a voltar de "mãos vazias"1 para o continente.

Agora, muitos decidiram escrever sobre isso - sobre como era a vida na colónia, sobre o que perderam, sobre o que ficou, sobre como foi "regressar" e viver com o estigma de "retornado" , buscando a sua identidade nos meandros de uma memória pessoal que era também uma história colectiva e tentando perceber o que é ser português hoje. Nos últimos anos, têm vindo a lume livros sobre a presença portuguesa em Âfrica: diários de guerra, ficções e autobiografias, mas também livros escritos por retornados (ou não) evocando a tragédia da ponte aérea ou as consequências do retorno na vida de muitos portugueses (RIBEIRO, 2010, 90).

Dentro dessa produção, nomeada por Isabel Ferreira Gould (2007, p. 65) de literatura de revisitação africana, como também de literatura de "retornados", segundo Sheila Khan (2010, p. 9), feita, sobretudo, pelos "órfãos" do colonialismo em África, em O retorno, de Dulce Maria Cardoso, conhecemos a história de Rui, em meio a um romance que tem como pano de fundo os acontecimentos da década de 70, cenário de mudanças efetivas e duradouras nas estruturas políticas que abrangeram Portugal e nos territórios antes colonizados. Assim, no livro, em decorrência da Guerra Colonial e da independência de Angola, revemos a trajetória dos portugueses que, em poucos meses, foram obrigados a abandonar Luanda e todo bem amealhado, e a retornar para Portugal.

A história de Rui, filho de portugueses, nascido em Luanda, inicia-se exatamente na viragem do ano de 1974 para 1975, mostrando-nos esse doloroso processo de migração forçada de muitos portugueses, que, como a sua própria família, construíram as suas vidas em Luanda.

\footnotetext{
${ }^{1}$ É importante ressaltar que aos retornados era vedada a transferência de bens para o continente. Se inicialmente a medida tinha a intenção de reter o capital em solo africano para que nele fosse investido, depois, mesmo com a independência das províncias ultramarinas, essa medida resultou: "numa verdadeira catástrofe para quem foi forçado a abandonar África. Os que voltaram para Portugal continental não puderam "trazer livremente os seus haveres; dinheiro, carros ou quaisquer outros bens materiais. Prédios, terrenos urbanos ou rústicos, fazendas, fábricas, estabelecimentos, imóveis de qualquer índole, estavam sentenciados a ficar; é mais que evidente que os seus possuidores todos os pretendiam vender mas, em face da situação, não havia quem se interessasse pela sua aquisição". Em: http://retornadosdafrica.blogspot.com.br/
} 
Na mesma noite em que o sr. Manuel partiu com a família no Príncipe Perfeito, fomos à farra da passagem do ano [...] o pai olhava para a multidão que dançava na festa [...] o conjunto desafinava mas ninguém deixava de dançar por causa disso, estava à toa na vida o meu amor me chamou, pra ver a banda passar cantando coisas de amor [...]1975 ia ser um ano bom, se calhar o melhor de nossas vidas, íamos deixar de ser portugueses de segunda, o futuro era aqui [Luanda], o pai estava certo apesar dos chaimites e dos tiros [...] Só que a banda nunca mais passou. Foi tudo tomando o seu lugar, cada um de nós no seu canto e em cada canto uma dor [...] os tiros e os morteiros não pararam, os pretos continuaram a vir de todo o lado e os brancos a irem-se embora, os tropas portugueses já nem da bandeira queriam saber e os comunistas da metrópole vieram para cá [...]. O pai calou-se sobre o futuro (CARDOSO, 2012, p. 29-33).

Em 1975, cerca de 300 mil portugueses abandonaram Angola, em meio a um clima de pessimismo, pois não havia em Portugal condições econômicas de acolhimento e integração social de toda essa massa de retornados. Além disso, entre 1974 e 1976, a violência crescia no território angolano até o limite de uma guerra civil. No entanto, o que podemos observar, pelo menos no discurso inicial de Rui, é um tom de esperança "cega" quanto ao futuro. Apesar dos ecos da violência generalizada que tomava conta da nação angolana e da debandada de muitos portugueses, havia ainda alguma certeza de que as bases fixadas em Luanda seriam reafirmadas, que as sementes lançadas ali dariam frutos. Temos, dessa forma, a impressão de que o discurso de Rui suscita, implicitamente, outro, de ordem histórica. Como se sabe, Portugal sempre esteve à sombra de um passado glorioso que se colocava como paradigma para as projeções temporais do presente e do futuro. Nesse sentido, estar preso ao passado equivale a estar preso a um modelo idealizado: a do país colonizador, com seus heróis e mitos, com suas batalhas e conquistas, que, no caso de $O$ retorno, simbolicamente se faz representar pela terra outrora conquistada: Luanda. Não é por outra razão que Rui e seu pai não querem acreditar na descolonização. Para eles, o passado ainda faz sombra no presente, portanto, o império não poderia ter chegado ao fim.

Essa esperança misturada ao sonho do colonizador, de prosperar a sua presença e onipresença num território que seria a garantia da riqueza do império colonial, não obstante, é atravessada por uma realidade das mais concretas e árduas: o processo de descolonização era evidente e já corria largamente Angola adentro ${ }^{2}$. Se o tom inicial do discurso de Rui deu-nos a impressão de certa esperança quanto ao futuro, as suas palavras finais, ainda na citação em epígrafe, dão-nos mostras da dor que foi envolvendo e desbotando os sonhos e as expectativas

\footnotetext{
${ }^{2}$ Quando, em meados dos anos 70, ocorreram os movimentos de derrubada das últimas ditaduras europeias (Grécia, Portugal e Espanha), as lutas coloniais de libertação ganharam força. Nesse âmbito, em Angola, surgem algumas organizações contra o colonialismo salazarista e para libertação de Angola, como o Movimento Popular pela Libertação da Angola (MPLA), fundando inicialmente em 1956 por Agostinho Neto, a União Nacional pela Independência Total de Angola (Unita), dirigida por Jonas Savimbi e a Frente Nacional de Libertação de Angola (FNLA), conduzida por Holden Roberto. A revolução de abril de 1974, que colocou fim na ditadura portuguesa, assegurou a assinatura do Acordo de Alvor, marcando a libertação angolana em 1975. Nota da autora.
} 
porvindouras, tanto que o pai, o centro estabilizador da família, calou-se diante do amanhã. E calar-se diante do amanhã não equivaleria a estar preso, de certa forma, ao momento presente sem projeções, pois, para o futuro?

Como não há saída, Rui embarca com sua mãe e irmã para Portugal, levando consigo poucos bens e diminutas esperanças, deixando para trás o pai, preso por suspeita de ação contra os negros: "quando voltei a mim o pai estava a ser metido no jipe com a sua própria arma apontada na cabeça" (CARDOSO, 2012, p. 76). Para trás também ficaram a casa e os sonhos de Rui. À vista disso, em $O$ retorno, conhecemos os sentimentos e as cicatrizes de uma geração que tem como porta-voz o adolescente Rui, responsável por tecer uma longa e emocionante reflexão em torno da experiência de ser um retornado ${ }^{3}$.

É válido ressaltar que Rui, cujo nome implicitamente se refere ao infinitivo do verbo ruir, também pode ser entendido como porta-voz da autora do romance. Nesse sentido, $O$ retorno poderia ser enquadrado como uma "narrativa de testemunho" (GOULD, 2007, p. 9) "a narrar um fato, na maioria das vezes, traumático e que, por determinadas razões, tem reverberações políticas, históricas e sociais". Por ter vivido ou conhecido alguém que viveu aquele acontecimento, o escritor julga importante registrar este ponto de vista sobre determinado evento. N' O retorno, pela dicção de Rui, entrevemos sutilmente a própria experiência de retornada de Dulce Maria Cardoso que, nascida em 1964 em Trás-os-Montes, ainda muito pequena, embarcou no navio Vera Cruz tendo como destino Angola, ao lado de tantos outros portugueses que encarnaram o sonho de fincarem raízes em África, a favor de uma terra que seria deles, não fosse os descaminhos que os levaram, tempos depois, a forçosamente terem de abandonar tudo, inclusive, o amor nutrido pela nova terra.

$\mathrm{O}$ adolescente protagonista do romance é o ponto de distanciamento mais cômodo e o caminho de discussão mais confortável para Dulce Maria Cardoso expurgar ficcionalmente tal experiência, traduzida numa história que se divide na ambivalência geográfica entre um lá, Luanda, a terra da infância e dos primeiros amores; e um cá, a "metrópole", o ideal desfeito: “já se foram todos embora. Os meus amigos, os vizinhos, os professores, os donos das lojas, o mecânico, o barbeiro, o padre, todos. Nós também já não devíamos cá estar” (CARDOSO,

\footnotetext{
${ }^{3}$ Interessante observarmos que Rui não é exatamente um "retornado", uma vez que nunca havia estado em Portugal continental. Esse termo, que foi arranjado pelo governo, com a criação do IARN (Instituto de Apoio aos Retornados Nacionais), era mais adequado aos que regressavam do ultramar. No caso de Rui, ele nasceu e cresceu numa colônia e, depois, acabou vindo parar em Portugal com sua mãe, esta sim uma retornada de fato, e irmã. Temos a impressão, assim, que todos os que estiveram nos territórios ultramarinos e pegaram a ponte aérea Luanda-Lisboa na situação de "retorno" foram "colocados no mesmo pacote" e receberam o mesmo rótulo. Nota da autora.
} 
2012, p. 11). Seu discurso, muitas vezes, ácido e ressentido, representa um desejo subliminar de vingança - vingança contra perdas irrecuperáveis.

Estamos aqui há quase um dia, a mãe está sempre a olhar para a porta do aeroporto mas o pai não chega, não há mais o que fazer senão esperar, esperar o pai e esperar a nossa vez no avião para a metrópole. Temos de esperar pelo Mário [...] não posso deixar cá ficar o Mário [...] não podemos deixar cá ficar o pai, a mãe sem tirar os olhos da porta do aeroporto (CARDOSO, 2012, p. 70-71).

A perda é exatamente a questão fulcral a ser explorada por Dulce Maria Cardoso na história de Rui, conforme se pode observar em entrevista da autora a Carlos Vaz Marques (2011, p. 30):

Os retornados que conheço e de que posso falar foram os mais injustiçados. Os bem-sucedidos seriam bem-sucedidos em qualquer parte do mundo porque eram pessoas muito fortes e capazes. A maior parte não foi muito bem-sucedida, só que dos fracos não reza a História. [...] Pensei numa proposta de reflexão sobre a perda, sobre o que terá sido o colonialismo, nas suas raízes mais subterrâneas. [...] Nunca deixei de ser uma retornada.

Entretanto, em oposição ao espaço da "colônia", onde tudo foi perdido, surge outro espaço, o da "metrópole", onde tudo poderia ser ganho, construído, na verdade, um lugar marcado pelas lembranças do passado e pelo desejo angustiante de toda uma vida que deveria seguir adiante. Destarte, o discurso de Rui, organizado segundo o momento e o local em que é formulado, é marcado pela ambivalência temporal, que se evidencia no eixo passado: o idílio que ficou para trás; e no presente: Lisboa e os seus dissabores. Em outras palavras, sua voz assevera uma ambientação dicotômica, já que, a partir de sua chegada, tudo passará a acorrer “cá”, local onde, embora Rui suspeitasse, deveria haver cerejas grandes e luzidias; mas tendo como principal paradigma "lá": Luanda.

O cenário, talvez, idílico de Portugal, construído em seu imaginário ao longo da vida passada em Luanda, portanto, logo será substituído por uma realidade das mais hostis, ou seja, por uma terra bem diferente das aulas de história ${ }^{4}$ e dos mapas das aulas de geografia.

Recebidos pelo IARN, o Instituto de Apoio ao Retorno de Nacionais, criado em 1975 pelo governo português de então, para apoio aos refugiados que chegavam, diariamente, das ex-colônias portuguesas de África, o grupo de Rui tem a "sorte” de ir para um hotel de cinco estrelas no Estoril, abarrotado de retornados.

\footnotetext{
${ }^{4}$ No blog Retornados da África, observamos que nas aulas de história era ensinado que Angola, bem como todas as outras províncias ultramarinas, constituíam parte integrante do grande império português, que fora legado aos portugueses pelos corajosos e gloriosos antepassados que deram novos mundos ao mundo através dos descobrimentos e eram senhores de aquém e além mar. Em: < http://retornadosdafrica.blogspot.com.br/>
} 
Sejam todos muito bem-vindos a este hotel. Façam o favor, entrem, podem sentar-se nessas poltronas [...] estejam à vontade [...] Sei pelo que estão a passar mas infelizmente não são os únicos. Não se preocupe com a mala minha senhora, o recepcionista toma conta delas. São circunstâncias terríveis mas não está ao alcance de nossa vontade mudá-las. São tempos conturbados [...] No meio do azar ainda tiveram sorte (CARDOSO, 2012, p. 67-69).

Na verdade, o hotel assemelha-se a um campo de refugiados, constituindo-se um ambiente de degradante frustração. O quarto 315 torna-se a nova casa de Rui: "um quarto pode ser uma casa e este quarto e esta varanda de onde se vê o mar é a nossa casa" (CARDOSO, 2012, p. 165). É nesse espaço que o adolescente aprenderá a viver cada dia, a adolescer por hora, na espera assombrada pelo retorno do pai. Enquanto isso, o garoto vai reinventando a vida passada e os amigos de Luanda, refazendo as suas histórias, reaprendendo a amar e a enfrentar a nova realidade.

Vou dar pontapés em todas as portas até chegar ao pátio do recreio, a puta da professora mandou-me para a rua com uma falta a vermelho mas eu vingo-me [...] A puta da professora, um dos retornados que responda, como se não tivéssemos nome, como se não bastasse ter-nos arrumado numa fila só para retornados (CARDOSO, 2012, p. 140).

A África torna-se cada vez mais o pretérito desejado, todavia para sempre perdido. Já é mais do que notória a ideia de que Portugal sempre esteve ligado ao seu passado grandioso e que tal sentimento continua presente no imaginário lusitano, como algo a ser resgatado para um futuro melhor. A saudade de um tempo ancestral, mítico e glorioso é marca da nação portuguesa, segundo Eduardo Lourenço (1999, p. 99-125). Se a identidade de uma nação está ligada a esse sentimento, analogamente as identidades dos sujeitos carregam consigo os arquétipos de sua nação. E, assim como Luanda se torna o não-lugar do decadente império, Portugal correlativamente se torna o não-lugar de Rui, que faz parte de um grupo de pessoas, filhos de Portugal, que tiveram de regressar a um país cujo governo não lhes pode oferecer mais do que vergonha e hostilidade. Afinal, segundo Guerra (2000, p. 100) a massa de retornados que correspondia a quase dez por cento da população portuguesa naquela altura, constituiu um impacto brutal sobre a já frágil e vulnerável economia.

De fato, cabia aos órgãos do poder instituído a difícil tarefa de proporcionar os meios necessários à integração social e econômica de cerca de meio milhão de desalojados do "Ultramar português", de forma relativamente rápida, de modo a minimizar os atritos sociais inevitáveis em situações deste tipo. Mas, apesar dos diversos programas governamentais de assistência, desenvolvidos pela Secretaria de Estado dos Retornados, depois transformada em Comissariado para os Desalojados, o regresso das tropas e dos civis portugueses que viviam nas ex-colônias agravaria a situação econômica e social vivida em Portugal, uma vez que contribuiu para aumentar o número de desempregados e piorar o déficit de moradias, fatos que alimentaram o clima de instabilidade política em vigor no país desde o imediato pós- 25 de Abril de 1974 até as eleições parlamentares de abril (PEIXOTO, 2011, p. 2) 
Não é por outra razão que a desconfiança por tudo e por todos passa a ser o sentimento mais comum a Rui. A hostilidade e a estranheza do próprio povo português face aos excolonos, aos retornados, acabam por trazer à tona, contrariamente, a angústia do sentimento de não-pertencimento. Essa crise vivenciada pelo adolescente protagonista do romance lembra-nos de algo explanado por Edward Said em Reflexões sobre o exílio (2003). Nesse livro, o autor aponta quão assustadora é a condição de vivência dos sujeitos fora de seus lugares de origem, ressaltando, como consequência, a terrível experiência que o exílio provoca. Para Said (2003, p. 47), eminentemente associada à experiência do degredo está a condição dolorosa e fatídica de se estar e se sentir "fora do lugar", vivenciada pelo sujeito deslocado de sua terra natal - seu berço, sua casa:

E, embora seja verdade que a literatura e a história contêm episódios heroicos, românticos, gloriosos e até triunfais da vida do exilado, eles não são mais do que esforços para superar a dor mutiladora da separação. As realizações do exílio são permanentemente minadas pela perda de algo deixado para trás para sempre (SAID, 2003, p. 46).

As longas viagens ultramarinas portuguesas empreendidas principalmente na época do quinhentismo proporcionaram aos portugueses a experiência da partida e do adeus a sua terra e da chegada e conquista de novas fronteiras. Se de um lado tal experiência reforçou o sentimento de apego e saudade à pátria, por outro os revestiu de força e coragem para enfrentamento e adaptação aos novos costumes. Mas entre a saudade e a coragem, certamente tais vivências se fizeram marcadas por desconfortos e desconfianças - sendo que "nãopertencer" equivaleria a mais uma forma de enfrentamento diante das circunstâncias diaspóricas.

Como expomos, no plano da ficção, a literatura portuguesa contemporânea tem se ocupado em retratar as angústias dos que experimentaram os dissabores do sentimento de mal-estar, principalmente relacionada às diásporas. Nessa mesma sequência, poderíamos relacionar a experiência de Rui a de uma personagem de um romance que tem como pano de fundo dos acontecimentos a emigração portuguesa e como principal cenário a França: Pouca terra...poucá terra (1984), de Júlia Nery. Nesse livro, escrito na década de 80, é possível conhecermos a história de Leonor, uma jovem universitária, que vive com sua avó, Maria Menina, e seus pais, Edgar e Maria da Luz, naquele país. Nas linhas gerais do romance, observamos a reconstituição, durante a viagem de férias/regresso da jovem Leonor (personagem/narradora) para Portugal, da história de uma vida marcada pela angústia do nãopertencimento - Leonor, que era francesa nos modos, porém essencialmente portuguesa nos 
sentimentos, passou a ser vista pelos seus conterrâneos lusitanos como uma estrangeira, maneira pela qual também era vista pelos franceses.

Em $O$ retorno, as sensações experimentadas por Rui são muito próximas daquelas sentidas por Leonor, personagem de um livro escrito, pelo menos, vinte e sete anos antes. Contudo, havemos de ressaltar uma diferença fundamental entre as duas personagens: Leonor sentia-se desconfortável porque, sendo portuguesa, era considerada, como consequência de seus costumes e modos, uma estrangeira em sua própria terra, assim como também o era em França. Já no caso de Rui, ele nasceu em Angola e Angola, como parte integrante do território português, era Portugal. Portanto, Rui era um cidadão português ${ }^{5}$, não sendo estrangeiro em Portugal. Esta já seria uma semelhança entre as personagens. Então, qual seria a assimetria entre ambas? Em $O$ retorno, a própria narrativa permite-nos observar, explicitamente, a imagem de um garoto cujo rótulo de "retornado" carregava consigo uma questão ainda mais complexa: por ter nascido em Luanda, por ser filho de portugueses "colonos" em África, ele era considerado pela maioria dos seus compatriotas, pelo menos, por aqueles que não partilharam da mesma experiência do ultramar, não como um estrangeiro, mas como um cidadão de segunda classe. O que notamos, em todo o caso, é que o sentimento de nãopertencimento, também marcado pela desconfiança do olhar do "outro," expressos nos dois protagonistas representam ou sugerem que os processos diaspóricos também podem ser formados por essas nuances.

\section{Retorno e resistência}

No instigante romance de Dulce Maria Cardoso, Luanda estará para sempre guardada na memória de Rui. Luanda e os amigos, Luanda e a escola, Luanda, a terra mágica e tropical, Luanda e os flertes da adolescência, Luanda e a amizade com o pai, o centro estabilizador de tudo.

\footnotetext{
5 "É sabido que antes de 11 de Novembro de 1975, altura em que Angola se tornou independente de Portugal, por força do fim da colonização, os angolanos eram considerados cidadãos portugueses por direito (para aqueles que não chegaram a obter registo civil e a constituir a respectiva nacionalidade por via documental) e nesse contexto podiam reclamar da nacionalidade portuguesa constituindo-se cidadãos de Portugal no pleno gozo dos seus direitos. Mesmo depois do nascimento da República Popular de Angola, os angolanos podiam até 1978 reclamar esse direito, visto que Angola tinha sido uma província de Portugal ao tempo da colonização". Para uma visão inicial em torno da questão da problemática das nacionalidades portuguesas e angolanas, sugerimos consultar: $\quad\langle\underline{\text { ttp: }: / \text { www.diarioangolano.com/index.php/opiniao/192-parceria-portugal-angola/9930-a- }}$ problematica-das-nacionalidades-portuguesa-e-angolana $>$.
} 
Nunca mais vamos dormir a sesta nas espreguiçadeiras, o pai nunca mais se vai sentar no banco de madeira para que o barbeiro lhe apare o cabelo e lhe faça a barba, um barbeiro branco, que só um doido deixava que um preto lhe pusesse uma navalha no pescoço (CARDOSO, 2012, p. 18).

O romance, marcado pelos dilemas existenciais e por reflexões que evidenciam marcas traumáticas de uma experiência singular, é um desabafo em torno da revolução, da perda do império, e daqueles que, ainda hoje, estão ou se sentem às margens da história. Ideologicamente, a descolonização na óptica de Rui instiga aversão e horror.

Estavam lá [no hotel] retornados de todos os cantos do império, o império estava ali, naquela sala, um império cansado, a precisar de casa e de comida, um império derrotado e humilhado, um império de que ninguém queria saber (CARDOSO, 2012, p. 86).

A crítica à revolução e os seus efeitos diretos na população portuguesa também é evidente. Vale lembrar que na África portuguesa, era mais ou menos comum a evolução ideológica dos grupos armados em direção de algum tipo de comunismo de face nacional. Essa tendência era forte e se fazia, sobretudo, pela subordinação da própria nação portuguesa à lógica sistêmica das correntes mais poderosas do capital oligopolista internacional. Nesse sentido, Secco (2005, p. 15) ressalta que "ideologias e interesses de europeus, soviéticos, norte-americanos também se inscreviam no espaço geográfico luso-africano," tendo como objetivo principal, senão elementar, o progresso da descolonização. No caso da forte influência do modelo soviético:

Mesmo os programas que fundamentaram os partidos guerrilheiros preferiam mais a velha ideia de nação ao socialismo, que se reduzia a uma mera referência no imbróglio ideológico desses tempos. Expliquemos melhor: as fontes ideológicas exógenas precisavam se adaptar ao solo específico da África porque, se é verdade que suas elites políticas buscavam no hemisfério norte sua inspiração, tais verticalidades precisavam ser superpostas, no que tange à mobilização social mais ampla, pelas horizontalidades. (SECCO, 2005, p. 15).

A impressão que temos é que a adoção do socialismo e o apoio irrestrito da União Soviética, como forças motrizes que impulsionaram a Guerra Colonial em Luanda, assim como seriam na própria conjuntura revolucionaria do 25 de abril, representaram uma oportunidade para o próprio progresso social.

A puta a justificar-se, os retornados estão mais atrasados, sim, sim, devemos estar, devemos ter
ficado estúpidos como os pretos, e os de cá devem ter aprendido muito depois da merda da
revolução, se for como em tudo o resto devem ter tido umas lindas aulas. Ainda agora não há
um dia em que não haja manifestações, bombas, ameaças, expropriações, ocupações, greves, há
sempre comunicados na televisão, já não é só do MFA, do Conselho da Revolução, do Copcon,
agora é das comissões, dos comitês, das cooperativas, são cada vez mais, não sei onde vão
buscar tantos revolucionários (CARDOSO, 2012, p. 139-140).

Na ambivalência entre o lá e o cá, entre ser um retornado e filho da ex-colônia, enxergamos a tensão de um garoto em meio a um cenário de difícil adaptação. $\mathrm{O}$ exílio, em $O$ 
retorno, pode ser entendido como uma situação fatídica que tem como destino um longo tempo de desconforto e incerteza. No livro Da diáspora, Stuart Hall (2011, p. 26-27) defende a ideia de que tal sensação acompanhará os sujeitos que, mesmo retornados, sentirão dificuldade em se religar a suas sociedades de origem. No caso de Rui, tanto Portugal quanto Angola eram a sua casa, o seu lar, por herança dos pais. Mas houve estranhamento no retorno a Portugal uma vez que a nação não pôde oferecer condições dignas aos retornados. Houve, porque eles foram desprezados e observados com desconfiança.

Acreditam que os pretos nos puseram de lá para fora porque os explorámos, perdemos tudo mas a culpa foi nossa e não merecemos estar aqui num hotel de cinco estrelas a sermos servidos como éramos lá. Os empregados preferem servir os pretos que nem nos talheres sabem pegar a servi-nos a nós, acham que os pretos são vítimas que ao fim de cinco séculos de opressão ainda tiveram de fugir da guerra (CARDOSO, 2012, p. 91-92).

E, dentro dessa perspectiva, a outra terra ultramarina continuou a ser o local idealizado, embora Rui se lembrasse de muitas mazelas também vivenciadas ali. $\mathrm{O}$ desconforto do não-pertencimento acaba sendo reforçado na relação entre o lá e o cá, não importando tanto onde se estivesse. O que era emergente e necessário para Rui é que o seu pai também retornasse, assumindo o controle da família daquele momento em diante.

Tanto que a estabilidade emocional de Rui e, consequentemente, da família, só se efetiva com a volta tão esperada e, antes, quase incerta, do pai. O romance, a partir de então, torna-se mais leve para os leitores, porque, desse momento em diante, é possível observarmos as esperanças se "renovarem" - se antes as suas vidas estavam limitadas ao eixo temporal passado-presente, agora um novo tempo começa a ser desenhado em seus sonhos e esperanças: o futuro.

\footnotetext{
Ninguém volta da morte mas o pai está à porta do nosso quarto. Um saco de viagem preto na mão, uma boina cinzenta e um casaco aos quadrados. Não consigo acreditar que é o pai [...] Estamos todos no quarto e tão felizes, o pai veio ter conosco, estamos todos juntos outra vez [...] o pai vai tirar-nos daqui, o pai vai arranjar maneira de nos tirar daqui [...]. Nunca mais estarei aqui (CARDOSO, 2012, p. 220, 238).
}

Futuro sonhado com certa desconfiança, sem dúvida, uma vez que nada é tão acalentador na escrita de Dulce Maria Cardoso. Em todo o caso, Rui e sua família acreditarão que nunca mais estarão num hotel, não nas mesmas condições. A pátria também não será abandonada. O pai volta desejoso de reconstruir a vida, jurando não deixar o país. Rui vai aprendendo uma nova lição, a de ficar e tentar, a de persistir, a lição exemplar da coragem contra o medo. Nem América, nem Brasil, nem África do Sul. O futuro, afinal, poderia ser ali "porque as coisas terríveis estão sempre a acontecer cá, lá, em todo o lado" (CARDOSO, 2012, p. 261). 


\section{Palavras de epílogo: a pátria sem um pai é um império a ruir}

Dulce Maria Cardoso é uma autora voltada para a intimidade dos sentimentos humanos. Sua escrita, talhada por uma sensibilidade que se volta para a natureza secreta dos relacionamentos e das vivências, revela, sobretudo, situações de desconforto a que os sujeitos são expostos, seja no cotidiano dos dias, ou, numa experiência de vida específica, como a vivenciada por Rui. Como procuramos expor, a história desse adolescente é acompanhada pelo sentimento de mal-estar. As suas palavras ressentidas não sugerem um amor tácito por uma nação imperial que sonhava sem máculas, ideal e perfeita, com "raparigas bonitas como só as da metrópole podem ser?” (CARDOSO, 2012, p. 7). Após a leitura do romance, restanos a impressão de que o exílio, na perspectiva autoral é, antes, uma ferida profunda na qual a história de Rui parece oferecer uma sutura, superficial, mas válida. Ao tornar-se porta-voz de uma geração, ao evidenciar os sentimentos que marcaram os dias de retorno a Portugal e o abandono compulsório de uma terra que havia aprendido a amar, Rui oferece uma alternativa de avaliação, ou, ao menos, de reflexão, em torno desse passado recente da história portuguesa. As cicatrizes desse tempo, por certo, ainda estão à mostra na memória daqueles que vivenciaram o sentimento de não-pertencimento. Podemos aventar que a literatura, nomeadamente a de retornados ou de revisitação africana, tem procurado por vias ficcionais, pelo resgate memorialístico e testemunhal desse tempo, abrir os olhos da sociedade atual para um acontecimento que jamais deveria ser varrido para debaixo do tapete ou cair em esquecimento. Na história ficcional de Rui a volta do pai é a metáfora de uma pátria que, pósRevolução dos Cravos, começava a consolidar um tempo novo, de ares democráticos, arrefecendo o trauma da perda. A esperança de Rui mistura-se à esperança de uma maioria por dias melhores. Portanto, nas páginas de $O$ retorno, ficamos com a impressão de que tudo passará, de que outras bandas tocarão os sonhos de Rui e de sua família, de que tudo poderá entrar nos eixos. Se "cumpriu-se o mar, e o império se desfez"6 esse mesmo mar visto da janela de seu quarto 315, num hotel no Estoril, dizia-lhe, afinal, que "o futuro pode ser onde se quiser" (CARDOSO, 2012, p. 266). No entanto, essa conjuntura apenas sugere-nos uma possibilidade de estabilidade frente a um futuro que se desenhará um dia após o outro. E é assim, pela incerteza futura, que termina a sua dicção nas páginas finais d'O retorno, em coro com a escrita de Dulce Maria Cardoso, sempre pronta a colocar os seus possíveis leitores no desconforto das dúvidas e das ambivalências.

\footnotetext{
${ }^{6}$ Talvez dispense referências, um dos poemas mais famosos de Mensagem: O Infante, de Fernando Pessoa.
} 


\section{Referências}

AUGUSTO, Claudio de Farias. A revolução portuguesa. São Paulo: Unesp, 2011.

BARRENO, Maria Isabel; HORTA, Maria Teresa; VELHO, Maria Velho da. Novas cartas portuguesas. São Paulo: Círculo do Livro, 1974.

CARDOSO, Dulce Maria. O retorno. 3 ed. Lisboa: Edições Tinta da China, 2012.

GOULD, Isabel Ferreira. Mulheres coloniais no novo romance português. Letras de Hoje, Porto Alegre, v. 42, n. 2, p. 65-74, junho, 2007.

GUERRA, João Paulo. Descolonização portuguesa: o regresso das caravelas. Lisboa: Círculo de Leitores, 2000.

HALL, Stuart. Da diáspora: identidades e mediações culturais. Belo Horizonte: Ed. UFMG, 2011.

KHAN, Sheila In: RIBEIRO, Raquel. Os retornados estão a abrir o baú. In: Ípsilon online. $2010 . \quad$ Disponível em: <http://fonoteca.cmlisboa.pt/mm/IMG/PUBPERIO/jornais/04614/pdf/100813Ipsilon.pdf >. Acesso em 07 jun. 2014.

MACHADO, Alleid R. Recortes da literatura portuguesa: do século XVIII à atualidade. Rio de Janeiro: Clube de Autores, 2012.

NERY, Júlia. Pouca terra...poucá terra... Lisboa: Rolim, 1984.

PAIVA, José Rodrigues de. Revolução, renovação: caminhos do romance português no século XX. In: MARTINS, Elizabeth Dias; PONTES, Roberto e Barros, LIMA, Patrícia Elainny.(Orgs.). Falas \& textos: escritos de literatura portuguesa. Fortaleza: Universidade Federal do Ceará, 2010.

LOURENÇO, Eduardo. Mitologia da saudade: seguido de Portugal como destino. São Paulo: Companhia das Letras, 1999. MARQUES, Carlos Vaz. Entrevista a Dulce Maria Cardoso. Revista Ler, n. 106, Out. 2011, p. 29-32.

PEIXOTO, Carolina. A mídia portuguesa e o retorno dos nacionais. Tese de doutoramento em Pós-Colonialismos e Cidadania Global. Centro de Estudos Sociais/ Faculdade de Economia da Universidade de Coimbra. 2011. Disponível em: < http://cabodostrabalhos.ces.uc.pt/n6/documentos/06-Carolina_Peixoto.pdf $>$. Acesso em jun. 2014.

PESSOA, Fernando. Mensagem. Lisboa: Parceria A.M. Pereira, 1934. Disponível em: < http://purl.pt/13966/3/\#/0>.

PETROV, Peter. (Org.). O romance português pós-25 de abril. Lisboa: Roma Ed., 2005.

RIBEIRO, Margarida Calafate. O fim da história de regressos e o retorno a África: leituras da literatura contemporânea portuguesa. In: Itinerâncias - percursos e representações da pós-colonialidade. $2012 . \quad$ Disponível em: <http://www.ces.uc.pt/myces/UserFiles/livros/1097_MCR_fim_hist_reg_Itinerancias.pdf $>$. Acesso em 2 maio 2014.

RIBEIRO, Raquel. Os retornados estão a abrir o baú. In: Ípsilon online. 2010, p. 6-12. Disponível em: <http://fonoteca.cmlisboa.pt/mm/IMG/PUBPERIO/jornais/04614/pdf/100813Ipsilon.pdf $>$. Acesso em 07 jun. 2014. 
ROANI, Gerson Luiz. Saramago e a escrita do tempo de Ricardo Reis. São Paulo: Scortecci, 2006.

SAID, Edward. Reflexões sobre o exílio e outros ensaios. Trad. Pedro Maia Soares. São Paulo: Companhia das Letras, 2003.

SECCO, Lincoln. 25 de abril de 1974: a Revolução dos Cravos. São Paulo: Companhia Ed. Nacional, 2005.

SERRÃO, Joel. A emigração portuguesa: sondagem histórica. 4 ed. Lisboa: Livros Horizonte, 1982.

Sites consultados:

<http://www.diarioangolano.com/index.php/opiniao/192-parceria-portugal-angola/9930-aproblematica-das-nacionalidades-portuguesa-e-angolana>. Acesso em 10 jun. 2014.

< http://retornadosdafrica.blogspot.com.br/>. Acesso em 10 jun. 2014.

< http://cabodostrabalhos.ces.uc.pt/n6/documentos/06-Carolina_Peixoto.pdf> Acesso em 10 jun. 2014.

<http://retornadosdafrica.blogspot.com.br/> Acesso em 10 jun. 2014. 